\title{
Temperature thresholds for germination in $\mathbf{2 0}$ short-range endemic plant species from a Greenstone Belt in southern Western Australia
}

\author{
A. Cochrane ${ }^{1,2}$ \\ 1 Biodiversity Conservation Science, Department of Biodiversity, Conservation and Attractions, Perth, WA, Australia \\ 2 Ecology, Evolution and Genetics, College of Medicine, Biology and Environment, Australian National University, Canberra, ACT, Australia
}

\author{
Keywords \\ Climate change; germination; short-range \\ endemics; temperature thresholds; warming.

\section{Correspondence} \\ A. Cochrane, Biodiversity Conservation \\ Science, Department of Biodiversity, \\ Conservation and Attractions, Locked Bag \\ 104, Bentley Delivery Centre, Perth, WA 6983 \\ Australia. \\ E-mail: anne.cochrane@dbca.wa.gov.au
}

\section{Editor}

J.F. Scheepens

Received: 17 August 2018;

Accepted: 12 December 2018

doi:10.1111/plb.12951

\section{ABSTRACT}

- The study of climate-driven effects on seed traits such as germination has gained momentum over the past decade as the impact of global warming becomes more apparent on the health and survival of plant diversity.

- Seed response to warming was evaluated in a suite of short-range endemic species from the biodiverse Greenstone Belt of southern Western Australia. The temperature dimensions for germination in 20 woody perennials were identified using small unreplicated samples over 6 weeks on a temperature gradient plate (constant and fluctuating temperatures between 5 and $40{ }^{\circ} \mathrm{C}$ ). These data were subsequently modelled against current and forecast (2070) mean monthly minimum and maximum temperatures to illustrate seasonal changes to germination timing and final percentage germination.

- All but one species attained full germination in at least one cell on the gradient plate. Modelling of the data suggested only minimal changes to percentage germination despite a forecast rise in diurnal temperatures over the next 50 years. Nine species were predicted to experience declines of between $<1 \%$ and $7 \%$, whilst 11 species were predicted to increase their germination by $<1 \%$ to $3 \%$. Overall, the speed of germination is predicted to increase but the timing of germination for most species shifts seasonally (both advances and delays) as a result of changing diurnal temperatures.

- The capacity of this suite of species to cope with warmer temperatures during a critical early life stage shows a degree of adaptation to heterogeneous environments. Predicting the effects of global change on terrestrial plant communities is crucial to managing and conserving plant diversity.

\section{INTRODUCTION}

Temperature stress is an environmental challenge for natural populations of plant species and one that is likely to become more widespread in the future. As global temperatures surge, the question is whether species will survive one of the most critical stages of a plant's life cycle - namely germination. Germination is cued to changes in the environment with temperature being one of the key drivers of this transition from seed to seedling (Probert 2000). Experimental studies have shown us that species respond strongly to environmental manipulations, and most species have temperature thresholds above (and below) which germination may decline or fail (Cochrane et al. 2011; Fernández-Pascual et al. 2013, 2015). Thresholds for germination can vary between species, populations and individuals (Hernández-Verdugo et al. 2001; Cochrane et al. 2014; Emery et al. 2017). Failure to germinate can have profound consequences for ecosystem processes affecting community composition, species abundance and population dynamics (Walck et al. 2011). There is also evidence to show that changing temperatures can influence seed germination timing (Roberts 1988), a particularly pertinent issue in fire-prone environments (Hudson et al. 2015). Timing of seedling emergence is especially important and can determine seedling establishment success and hence the probability of surviving to the next generation (Donohue 2005b).

Western Australia has a highly variable climate. The southwest portion of the state experiences a seasonal mediterranean climate with hot dry summer and cool wet winters and is situated on the temperate margin of a dry continent. The predominantly sclerophyllous endemic flora has evolved on nutrientdeficient highly weathered soils, with an extraordinarily high turnover of species across the landscape (Hopper \& Gioia 2004). Germination of this flora occurs predominantly during the cool rainy months of autumn and winter at temperatures which are best suited for seedling establishment (Bell et al. 1993). However, between 1910 and 2013 this region experienced average annual temperature increases of $1.1{ }^{\circ} \mathrm{C}$ (Hope et al. 2015). By the end of the century under a high greenhouse gas emission scenario (Representative Concentration Pathway, RCP 8.5) the region is forecast to experience a $13 \%$ decline in mean annual precipitation (MAP), $17 \%$ increase in mean annual temperature (MAT) and $20 \%$ and $15 \%$ increase in mean monthly minimum and maximum temperatures, 


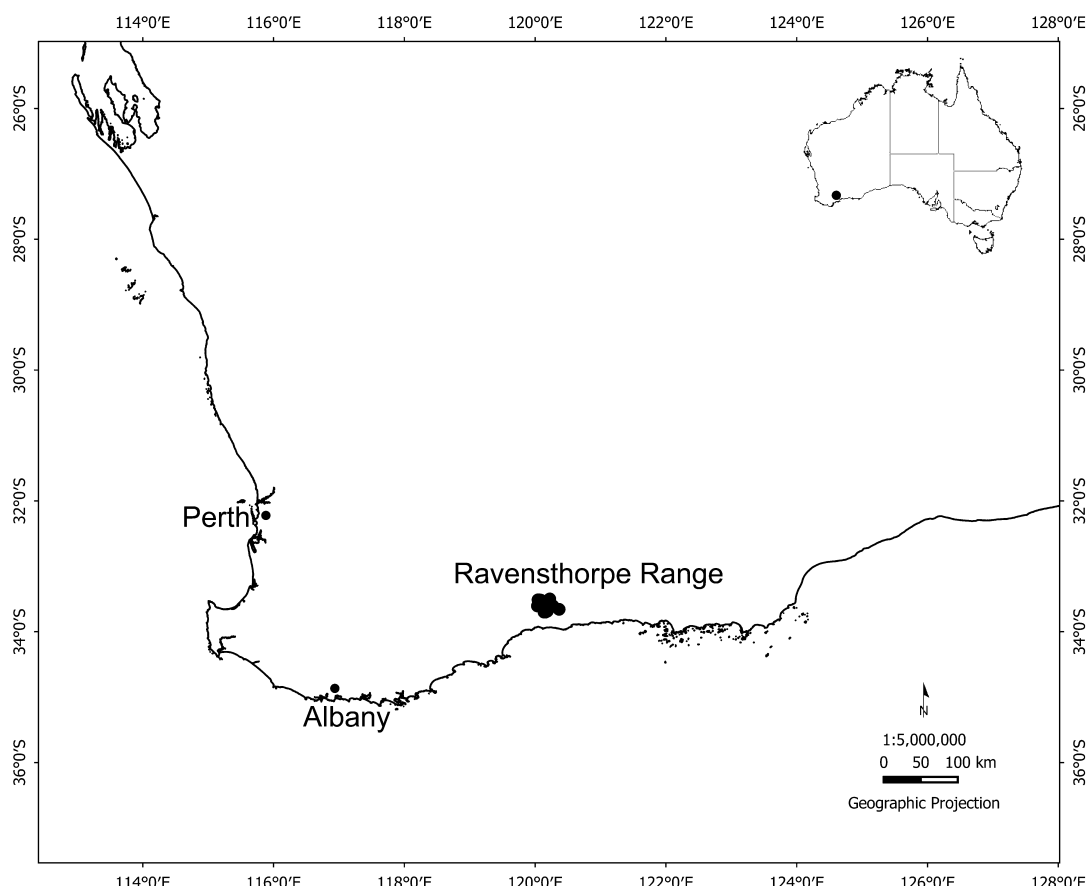

Fig. 1. Map of the Ravensthorpe Range with collecting sites for each of the species. respectively (source: www.worldclim.org). Temperatures are expected to rise in winter and spring as rainfall declines, spring will occur earlier and winter later, and these warmer, drier conditions are expected to impact on less heat-tolerant species that rely on cool wet winter seasonal conditions to germinate.

The Ravensthorpe Range is located in southern Western Australia (Fig. 1). This area is internationally renowned for its rich floristic diversity and endemism (Hopper \& Gioia 2004; Wilkins et al. 2011) and is one of 35 global biodiversity hotspots (Mittermeier et al. 2011). The Range falls within the UNESCO-listed Fitzgerald Biosphere, one of Australia's 14 biosphere reserves. Extending for approximately $50 \mathrm{~km}$ from $\mathrm{Mt}$ Short in the northwest to Bandalup Hill in the southeast, the Range has its highest point only $453 \mathrm{~m}$ a.s.l. Here, two-thirds of the annual rainfall occurs between May and October, but rainfall patterns can be variable and large rainfall events have been known to occur during the summer months. The coldest month is July with a daily mean of $16^{\circ} \mathrm{C}$, and the hottest month is January with a daily mean of $29^{\circ} \mathrm{C}$.

This Greenstone Belt is comprised of a broad range of rock types, from banded ironstone to komatiite, and a selection of metamorphosed sedimentary formations (Witt 1997). The Range has a history of mining, in particular copper and gold, and the surrounding areas have been heavily cleared for agriculture. The geology, topography and soil types of the Ravensthorpe Range are unique in the region, and in 2012 some 64 plant species in the Range were identified as being short-range endemics, i.e. species with naturally small distributions of less than $10,000 \mathrm{~km}^{2}$ (Markey et al. 2012). Many of these species are dispersal-limited as a result of habitat fragmentation. Despite the high conservation value of the Range's unique flora, only two small areas have been set aside as A-class nature reserves (those afforded the greatest protection), and ongoing mining and exploration activities present a significant challenge to conservation (Markey et al. 2012). Species inhabiting biodiversity hotspots are generally restricted to edaphic conditions fixed in the landscape, making them vulnerable to changing climates and further habitat destruction (Hopper \& Gioia 2004). It is thought that such species may have specific germination strategies that will assist them in coping with and tracking suitable conditions over time (Torres-Martínez et al. 2017); however, warming is nevertheless predicted to reduce plant recruitment under global warming scenarios (Walck et al. 2011).

The study of climate-driven effects on seed germination traits has gained momentum over the past decade, with modifications to temperature and rainfall expected to result in changes to plant community composition, species abundance and their distribution (Walck et al. 2011). Many of these studies have focussed on single species (e.g. Fernández-Pascual et al. 2015) or congeneric species (e.g. Cochrane 2016, 2017), with less prominence placed on investigating the impact of a warming climate on germination traits in plant communities per se (although see Bernareggi et al. 2016; Cochrane et al. 2011; Milbau et al. 2009). Consequently, this paper examines seed germination response to warming in 20 co-occurring short-range endemic plant species from the biodiverse Greenstone Belt of southern Western Australia. Divergence in traits of sympatric and closely related species can help explain species co-existence (Daws et al. 2002) in particular regeneration strategies (Grubb 1977). However, seed traits of communities of short-range endemics have been poorly explored despite their vulnerability to changing environmental conditions. For this suite of species from the Ravensthorpe Range area, the temperature requirements for germination were hypothesised to be narrow as a consequence of the species' restricted distributions and classification as short-range endemics. The expectation was that species from this cool winter rainfall region would show a reduction in germination by 2070 relative to current conditions, and that germination timing would shift as a result of the forecast seasonal changes. The optimum timing for successful germination should be during the cooler winter months but 
is hypothesised to show a seasonal shift to avoid mismatch between temperature cues for germination and prevailing environmental conditions forecast for the year 2070 .

\section{MATERIAL AND METHODS}

\section{Species and seed collection}

Of the 64 short-range endemic taxa known from the Greenstone Belt of the Ravensthorpe Range area (Markey et al. 2012), germination trials were conducted on 20 species representing ten genera from four families (Table 1; Fig. 1). Eleven of these species are species of conservation concern in Western Australia (threatened or poorly known) (Smith \& Jones 2018), while the remaining nine are common although restricted in distribution. The majority of species co-occur with at least one other within their range, with the exception of Kunzea acicularis which has a very restricted distribution northeast of the Range. All species are woody perennials, ranging from a semiprostrate shrub ca. $0.5-\mathrm{m}$ tall (Acacia bifaria) to trees that can attain a height of $10 \mathrm{~m}$ (Eucalyptus megacornuta and E. stoatei). Most of the species flower in spring, although this can vary depending on the season, and for non-serotinous species fruit is generally ripe by late summer. The exact timing of recruitment is not known for most species, and for a number the emergence of seedlings may be constrained to the post-fire environment (e.g. Allocasuarina, Banksia and Isopogon). At least three species are obligate resprouters.

Seeds were collected from up to 50 individual maternal plants per species from wild populations and bulked for germination purposes. Collections were made between 2002 and 2017, and older collections were dried at $15{ }^{\circ} \mathrm{C}$ and $15 \%$ relative humidity before storage in a seed bank before later use. Eight species in the family Fabaceae have hard seed and therefore exhibit physical dormancy; the remaining species have seeds that once released from fruits are generally non-dormant (Cochrane et al. 2002). Burning of woody fruiting cones was required in one species (Banksia) to enable seeds to be released.

\section{Experimental design}

A bi-directional temperature gradient plate (TGP) (GRD1; Grant Instruments, Cambridge, UK) was used to deliver 196 different temperature combinations between 5 and $40{ }^{\circ} \mathrm{C}$ (constant and alternating) simultaneously (Figure S1). The TGP allows the detection of thresholds more accurately than stepwise temperatures delivered by incubators, characterising a fuller spectrum of responses to future temperature scenarios. In this way, two axes of the thermal niche for germination minimum and maximum thermal limits - were investigated. The methods used for the experiment are as per Cochrane (2016). Seeds were sown in 30-mm plastic Petri dishes on $0.75 \% \mathrm{w} / \mathrm{v}$ water agar. Seed numbers per dish ranged from ten to 20 depending on species, and each species was exposed to 49 temperature combinations with a 12-h photoperiod for 6 weeks (four species per run of the TGP). Temperature conditions cannot be replicated during a run on the TGP so each temperature condition was represented by only one dish. Each seed was treated as an independent unit. Consequently, there is the potential for confounding effects in the data analyses due to absence of replication, which is duly acknowledged. Each
Table 1. List of species investigated including conservation status, fire response and seed mass (seeds per gram). DRF denotes Declared Rare Flora gazetted under the Western Australian Wildlife Act 1950. Daviesia megacalyx is also listed as Endangered under the Commonwealth of Australia Environment Protection and Biodiversity Conservation (EPBC) Act 1999. Species listed as P1-P4 are data-deficient and ranked in order of priority for survey and evaluation of conservation status so that consideration can be given to their declaration as threatened flora. Conservation status as per Smith \& Jones (2018); fire response as per Barrett et al. (2009).

\begin{tabular}{|c|c|c|c|c|}
\hline species and authority & family & $\begin{array}{l}\text { conservation } \\
\text { status }\end{array}$ & $\begin{array}{l}\text { fire } \\
\text { response }\end{array}$ & $\begin{array}{l}\text { seeds } \\
\text { per } \\
\text { gram }\end{array}$ \\
\hline Acacia besleyi Maslin & Fabaceae & P1 & OSS & 217 \\
\hline Acacia bifaria Maslin & Fabaceae & P3 & $?$ & 185 \\
\hline Acacia disticha Maslin & Fabaceae & & OSS & 137 \\
\hline Acacia durabilis Maslin & Fabaceae & & OSS & 645 \\
\hline $\begin{array}{l}\text { Acacia heterochroa } \\
\text { Maslin subsp. } \\
\text { heterochroa }\end{array}$ & Fabaceae & & OSS & 115 \\
\hline $\begin{array}{l}\text { Acacia ophiolithica } \\
\text { R.S.Cowan \& Maslin }\end{array}$ & Fabaceae & & OSS & 532 \\
\hline $\begin{array}{l}\text { Acacia pinguiculosa } \\
\text { R.S.Cowan \& Maslin } \\
\text { subsp. pinguiculosa }\end{array}$ & Fabaceae & & OSS & 339 \\
\hline $\begin{array}{l}\text { Allocasuarina } \\
\text { hystricosa Wege }\end{array}$ & Casuarinaceae & P4 & RS & 717 \\
\hline $\begin{array}{l}\text { Banksia laevigata } \\
\text { Meisn. subsp. } \\
\text { laevigata }\end{array}$ & Proteaceae & P2 & OSC & 28 \\
\hline $\begin{array}{l}\text { Beaufortia orbifolia } \\
\text { F.Muell. }\end{array}$ & Myrtaceae & & OSS & 3450 \\
\hline $\begin{array}{l}\text { Calothamnus roseus } \\
\text { A.S.George }\end{array}$ & Myrtaceae & P1 & $?$ & 4290 \\
\hline $\begin{array}{l}\text { Daviesia megacalyx } \\
\text { Crisp }\end{array}$ & Fabaceae & DRF & OSS & 50 \\
\hline $\begin{array}{l}\text { Eucalyptus cernua } \\
\text { Brooker \& Hopper }\end{array}$ & Myrtaceae & & OSC & 2809 \\
\hline $\begin{array}{l}\text { Eucalyptus } \\
\text { desmondensis } \\
\text { Maiden \& Blakely }\end{array}$ & Myrtaceae & P4 & RS & 2059 \\
\hline $\begin{array}{l}\text { Eucalyptus } \\
\text { megacornuta } \\
\text { C.A.Gardner }\end{array}$ & Myrtaceae & & OSC & 383 \\
\hline $\begin{array}{l}\text { Eucalyptus stoatei } \\
\text { C.A.Gardner }\end{array}$ & Myrtaceae & P4 & OSC & 459 \\
\hline $\begin{array}{l}\text { Isopogon sp. } \\
\text { Ravensthorpe (D.B. } \\
\text { Foreman 1207) }\end{array}$ & Proteaceae & & RS & 402 \\
\hline $\begin{array}{l}\text { Kunzea acicularis } \\
\text { Toelken \& G.F.Craig }\end{array}$ & Myrtaceae & DRF & OSS & 11170 \\
\hline $\begin{array}{l}\text { Melaleuca penicula } \\
\text { (K.J.Cowley) Craven }\end{array}$ & Myrtaceae & P2 & $?$ & 2553 \\
\hline $\begin{array}{l}\text { Melaleuca } \\
\text { stramentosa Craven }\end{array}$ & Myrtaceae & P2 & OSC & 4115 \\
\hline
\end{tabular}

OSS = obligate seeder with soil stored seed bank; OSC = obligate seeder with canopy stored seed bank; RS = resprouter.

species was however represented by between ca. 490 and 980 seeds.

Physical dormancy was overcome by manually scarifying seed with a scalpel to overcome hard seededness prior to 
incubation. Although non-dormant, the hairy nut of a further species, Isopogon sp. Ravensthorpe, was also manually scarified to aid germination (Cochrane unpublished data). A $10 \%$ diluted solution of smoked water as Regen 2000 Smokemaster ${ }^{\circledR}$ was applied to seeds of Kunzea acicularis (family Myrtaceae) for $24 \mathrm{~h}$ prior to rinsing in deionised water (DI) and incubation, as this has been shown to improve germination in this genus (Cochrane unpublished data).

Seed germination was checked three times per week and germinated seeds showing a radicle at least double the length of the seed were removed. At the end of the experiment, seeds with a hard, white endosperm were considered potentially viable; empty seeds were removed from the original count.

\section{Data analysis}

To define the response curves for each species and identify the optimal mean and diurnally alternating temperature conditions for germination (percentage germination, time to first germination, time to $50 \%$ germination and mean time to germination) regression models were fitted to the empirical data from the TGP experiment as per Cochrane $(2016,2017)$. The proportion of seeds that germinated per dish and mean time to germination were the dependent variables in logistic and ordinary linear regression models, respectively. Each seed was treated as an independent unit (i.e. it could either germinate or not) in the logistic regression using a log link function. Mean time to germination (MTG) as calculated for all temperatures (where germination occurred) used the equation: MTG = $(n \times d) / N$, where $n$ is the number of seeds germinated between scoring intervals; $d$ is the incubation period in days at that time point; and $N$ is the total number of seeds germinated. In addition, time in days to the onset (lag) of first germination $\left(T_{0}\right)$ and time to $50 \%$ germination $\left(T_{50}\right)$ were also calculated. General linear regression was used to examine the relationship between germination rate $\left(T_{0}, T_{50}\right.$ and MTG) and the mean of the diurnal temperatures that provided most rapid and complete germination (defined as mean $T_{\text {opt }}$ ).

Four alternative models were built to assess seed response to forecast warming for the region. Mean monthly minimum and maximum temperatures for each seed source site were used as proxies for thermal tolerance and were obtained from Version 2 of WorldClim (www.worldclim.org), a set of global climate layers with a spatial resolution of approximately $1 \mathrm{~km}^{2}$ (Fick \& Hijmans 2017). The data for 'current' conditions were derived from 1970 to 2000 averages. Future projections for the same climate variables were downloaded from the down-scaled Hadley Centre Global Environment Model Version 2 (HadGEM2ES; http://www.metoffice.gov.uk/research/modelling-systems/ unified-model/climate-models/hadgem2) using a high greenhouse gas emission scenario (Representative Concentration Pathway, RCP 8.5) for 2070. The RCP 8.5 scenario reflects high energy demand and greenhouse gas emission without climate change policies (Moss et al. 2010). This scenario is extreme but reflects a likely climate outcome given the current level of mitigation activity. The HadGEM2-ES model (Jones et al. 2011) includes dynamic vegetation, ocean biology and atmospheric chemistry, and has previously been used in simulating germination response in native species (Fernández-Pascual et al. 2015; Cochrane 2016, 2017) including use in the Fifth Assessment Report of the Intergovernmental Panel on Climate
Change (IPPC 2013). The temperature values for each cell of the gradient plate (diurnal temperatures, average of day/night temperatures, and amplitude of temperature range) were used as the independent variables to populate the models. The first model used the day and night temperatures within each cell as independent variables (model 1); the second (model 2) used the mean temperature of each cell as the independent variable; model 3 used the amplitude of temperature fluctuation in each cell; and model 4 used the mean as well as the amplitude of daily temperature variation. To allow for possible non-linear responses to temperature, the squares of temperature variables were included in each model. In all models a binary variable was included denoting the timing of light during the diurnal cycle (i.e. whether light coincided with the warm or cool part of the cycle) as one half of the cells on the temperature gradient plate had both day and night phases when temperature was higher (the latter being ecologically meaningless). Goodnessof-fit (Pearson's correlation coefficient, Pearson's $R$ ) was used to choose one of the four alternate models for germination for each species. Measures of goodness of fit summarise the discrepancy between observed values and the values expected under the model in question. Using the model with the best fit as described above, the responses under current and forecast mean monthly minimum and maximum temperature conditions were predicted using the fitted values, thus providing a germination response for each month of the year. From these data optimal timing of germination was derived. Although temperatures have risen considerably over these three decades (http://www.bom.gov.au/climate/current/annual/aus/), these are the averages used in the model and roughly represent the conditions under which many of the standing plants in the population would have experienced when they first emerged.

Statistical analysis was conducted in GenStat (18th edition; VSN International, Hemel Hempstead, UK); contour plots showing germination on the bi-directional temperature gradient plate were created using Origin 9.1 (OriginLab, Northampton, MA, USA).

\section{RESULTS}

\section{Empirical data}

Germination was uniformly high (100\%) in at least one cell on the temperature gradient plate (TGP) for all species, with the exception of Isopogon sp. Ravensthorpe which only achieved $67 \%$ germination of viable seeds in one cell within the 6 -week incubation period. A range of potentially viable seed remained in each cell, suggesting that temperature was the inhibiting factor to germination. However, remaining seeds were not reincubated at the optimum temperature for germination to determine whether they were able to recover. There was considerable variation in the temperature dimensions for germination and its timing across the 20 species investigated, with the contour plots presented in Fig. 2 illustrating the species-specific nature of seed responses to temperature. Mean time to germination (MTG) for seeds at their optimal temperatures ranged from 6 to 28 days (M. penicula and E. cernua, respectively). Across the 20 species the average MTG for final germination was 14.5 days. First germination typically occurred at 10 days after the commencement of incubation but varied between 4 and 25 days (M. penicula and Isopogon sp. Ravensthorpe, 

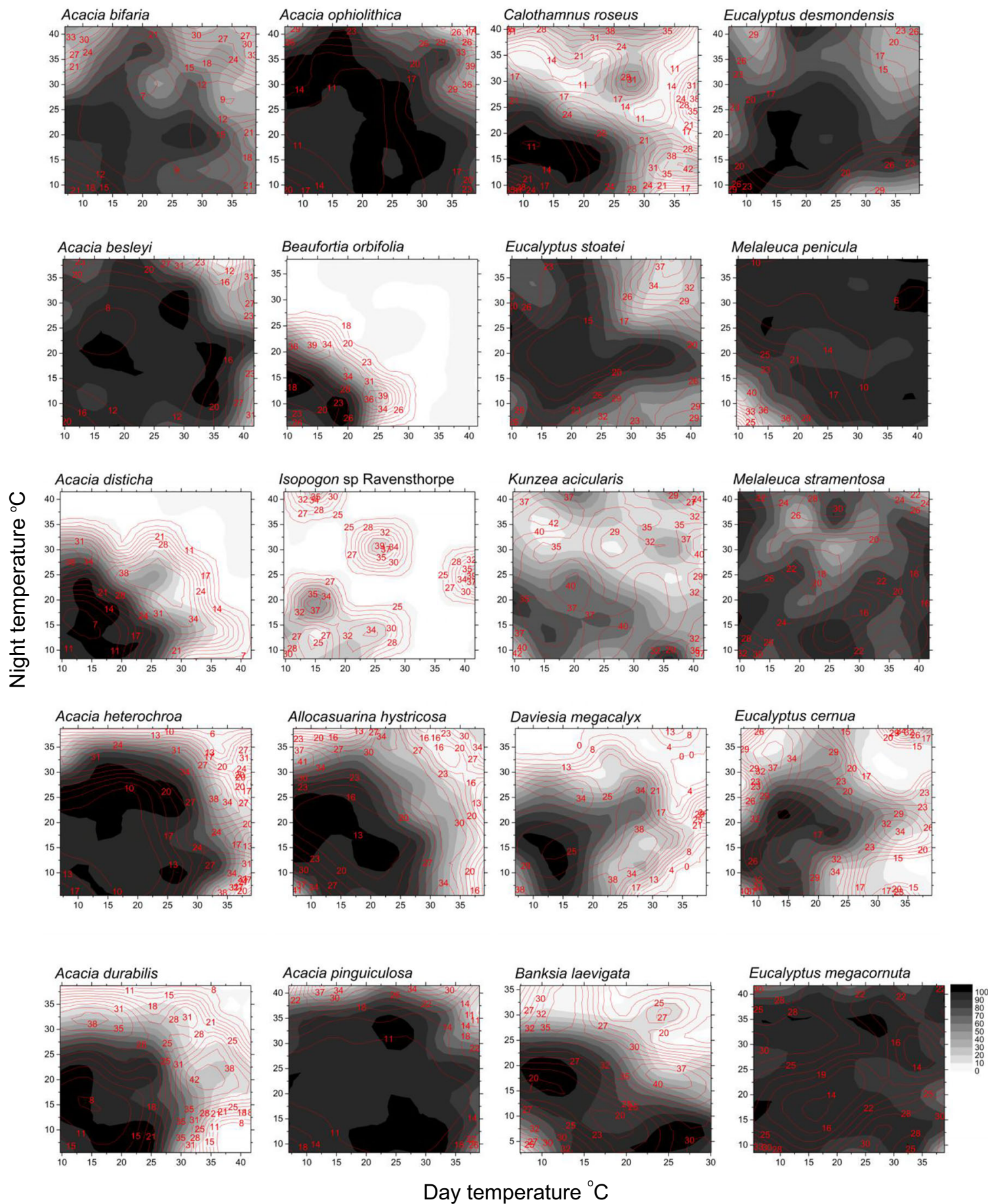

Day temperature ${ }^{\circ} \mathrm{C}$

Fig. 2. Contour plots, with points of equal percentage germination connected by germination isopleths for seeds of 20 short-range endemic species from southwest Western Australia. The shading calibration (bottom right) denotes percentage germination, with dark filling isopleths representing high germination and light filling low or no germination. Constant temperatures are across the diagonal from the bottom-left corner of the diagrams (lowest temperature approximately $\pm 5^{\circ} \mathrm{C}$ ) to the top-right corner (maximum temperature approximately $\pm 40^{\circ} \mathrm{C}$ ). All points above and below the diagonal represent alternating temperature regimes, with greatest amplitude at the top-left and bottom-right corners of each graph. Labelled contour lines represent mean time to germination in days.

respectively). The average time for seeds to achieve $50 \%$ germination was ca. 14 days, but varied between 7 and 42 days depending on the species.

The results for the 20 species showed some emerging trends. Four species (A. disticha, Banksia laevigata, Beaufortia orbifolia and Daviesia megacalyx) had reasonably low and constrained temperature windows for germination, with optimal mean temperature for germination $\left(\mathrm{T}_{\text {opt }}\right)$ being less than $15^{\circ} \mathrm{C}$ (Table 2). In contrast, $M$. penicula demonstrated an unusually high thermal preference for germination, with a mean $T_{\text {opt }}$ of 
Table 2. Observed data recorded from the temperature gradient plate (TGP) illustrating the optimum diurnal temperatures $\left({ }^{\circ} \mathrm{C}\right)$ and their mean and amplitude for maximum germination (TGP \% germ). Germination rates are expressed as time to initiate germination $\left(T_{0}\right)$, time to $50 \%$ germination ( $\left.T_{50}\right)$ and mean time to germination (MTG).

\begin{tabular}{|c|c|c|c|c|c|c|c|c|}
\hline species & $\begin{array}{l}\text { TGP day } \\
\text { temp }\end{array}$ & $\begin{array}{l}\text { TGP } \\
\text { night temp }\end{array}$ & $\begin{array}{l}\text { mean } \\
\text { TGP temp }\end{array}$ & amplitude & $\begin{array}{l}\text { TGP } \\
\% \text { germ }\end{array}$ & $\begin{array}{l}T_{0} \\
\text { (days) }\end{array}$ & $\begin{array}{l}T_{50} \\
\text { (days) }\end{array}$ & $\begin{array}{l}\text { TGP MTG } \\
\text { (days) }\end{array}$ \\
\hline Acacia besleyi & 22.1 & 15 & 18.6 & 7.1 & 100 & 6 & 8 & 7.2 \\
\hline Acacia bifaria & 28.4 & 19.3 & 23.9 & 9.1 & 100 & 6 & 8 & 9.5 \\
\hline Acacia disticha & 15.0 & 13.8 & 14.4 & 1.2 & 100 & 7 & 7 & 7.4 \\
\hline Acacia durabilis & 16.6 & 15 & 15.8 & 1.6 & 100 & 6 & 8 & 8.2 \\
\hline Acacia heterochroa & 17.7 & 16.6 & 17.2 & 1.1 & 100 & 6 & 6 & 6.4 \\
\hline Acacia ophiolithica & 19.3 & 17.7 & 18.5 & 1.6 & 100 & 7 & 7 & 7.7 \\
\hline Acacia pinguiculosa & 23.0 & 19.3 & 21.2 & 3.7 & 100 & 6 & 8 & 7.7 \\
\hline Allocasuarina hystricosa & 17.7 & 16.6 & 17.2 & 1.1 & 100 & 9 & 11 & 12.4 \\
\hline Banksia laevigata & 13.8 & 13.1 & 13.4 & 0.7 & 100 & 17 & 17 & 20.1 \\
\hline Beaufortia orbifolia & 16.4 & 9.9 & 13.2 & 6.5 & 100 & 7 & 7 & 17.9 \\
\hline Calothamnus roseus & 19.1 & 12.6 & 15.9 & 6.5 & 100 & 9 & 9 & 10.5 \\
\hline Daviesia megacalyx & 16.6 & 12.3 & 14.5 & 4.3 & 100 & 20 & 25 & 25.8 \\
\hline Eucalyptus cernua & 22.1 & 12.3 & 17.2 & 9.8 & 100 & 11 & 32 & 27.9 \\
\hline Eucalyptus desmondensis & 24.9 & 23 & 24.0 & 1.9 & 100 & 7 & 7 & 7.7 \\
\hline Eucalyptus megacornuta & 19.6 & 16.5 & 18.1 & 3.1 & 100 & 8 & 13 & 13.8 \\
\hline Eucalyptus stoatei & 22.1 & 20.3 & 21.2 & 1.8 & 100 & 7 & 11 & 10 \\
\hline Isopogon sp. Ravensthorpe & 19.3 & 15 & 17.2 & 4.3 & 67 & 25 & 42 & 42 \\
\hline Kunzea acicularis & 36.4 & 8.3 & 22.4 & 28.1 & 100 & 22 & 27 & 26 \\
\hline Melaleuca penicula & 36.4 & 27.7 & 32.1 & 8.7 & 100 & 4 & 7 & 6.1 \\
\hline Melaleuca stramentosa & 25.7 & 13.8 & 19.8 & 11.9 & 100 & 11 & 16 & 16.2 \\
\hline
\end{tabular}

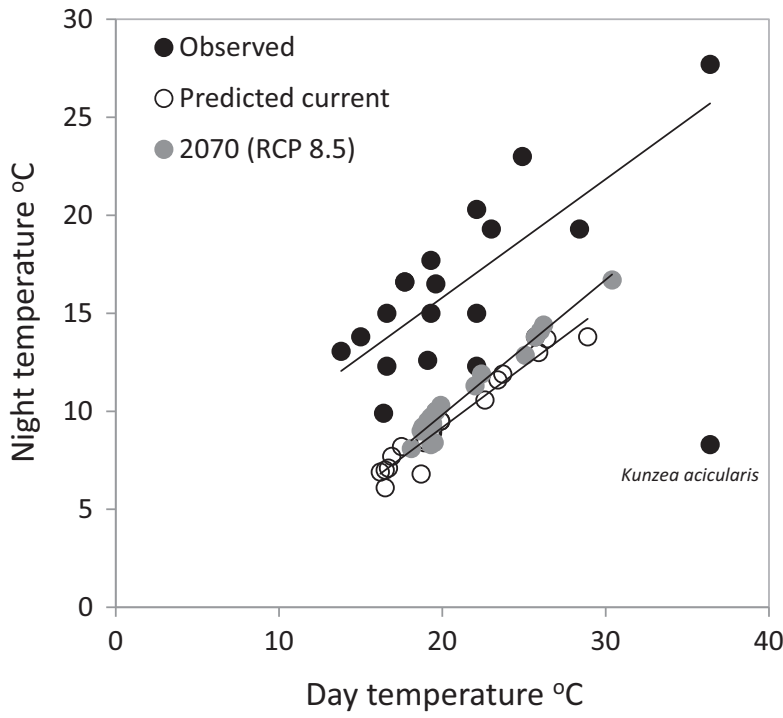

Fig. 3. Comparison between observed percentage germination data recorded from the temperature gradient plate, and the predictions for germination under current temperature regimes (1950-2000) and future (2070) temperature regimes under a high emission scenario. The observed data for Kunzea acicularis is an outlier and the regression line omits this point.

$32{ }^{\circ} \mathrm{C}$. Across the species, there was no overriding preference for constant over large alternating temperature regimes (or vice versa) for germination with the exception of $K$. acicularis seeds that required a large diurnal temperature range $\left(36 / 8{ }^{\circ} \mathrm{C}\right)$ to rapidly reach $100 \%$. The contour plots (Fig. 2) suggest that the timing of light during the diurnal cycle was of little significance for most species.
For each species, the mean diurnal temperature for germination was plotted against time to first germination $\left(T_{0}\right)$ and time to $50 \%$ germination $\left(T_{50}\right.$; Figure $\left.\mathrm{S} 2\right)$. These data demonstrate the spread of temperatures over which germination could occur, the majority showing a tendency for rate of germination to decline with increasing temperatures. Simple linear regressions showed there was no relationship between mean temperature for optimum germination and percentage germination, time to initiate germination $\left(T_{0}\right)$ or time to $50 \%$ germination $\left(T_{50}\right)$. However, there was a significant relationship between night time temperature and percentage germination $(F=7.1$, $P=0.016, \mathrm{df}=19)$, but night temperature only explained $24.3 \%$ of the variance in germination. The amplitude of the diurnal temperature regime was not a significant factor in determining temperatures optimal for germination, and this became obvious when the observed data were modelled (see below).

\section{Modelling of future responses}

The observed data (Table 2) were used in models to predict germination under current (1970-2000) diurnal temperatures for the 12 months of the year and then to model seed responses against monthly temperature conditions forecast for the year 2070 under a high emission scenario (RCP 8.5). Model 4 incorporating diurnal temperatures best explained germination responses (29 out of 79 models), while model 1, which used the amplitude and the mean of the diurnal temperatures, was the next best model to explain variation in germination rate variables (MTG, $T_{0}$ and $T_{50}$ ) but not final percentage germination (22 models). Model 2 (mean temperatures only) explained germination response almost as well as model 1 (21 models). Species responses generally followed no specific model $(1,2$ or 
Table 3. Modelled data for current (1970-2000) and 2070 (RCP 8.5 high emission greenhouse gas scenario), illustrating the optimum diurnal temperatures and their mean $\left({ }^{\circ} \mathrm{C}\right)$ for maximum germination (\%germ) and the time of year (month) when germination is predicted to be optimal. Germination rate is expressed as mean time to germination (MTG).

\begin{tabular}{|c|c|c|c|c|c|c|c|c|c|c|c|c|c|c|c|c|}
\hline \multirow[b]{2}{*}{ species } & \multicolumn{8}{|c|}{ predicted current data } & \multicolumn{8}{|c|}{ modelled future data } \\
\hline & $\begin{array}{l}\text { day } \\
\text { temp }\end{array}$ & $\begin{array}{l}\text { night } \\
\text { temp }\end{array}$ & month & $\begin{array}{l}\text { mean } \\
\text { temp }\end{array}$ & $\begin{array}{l}\% \\
\text { germ }\end{array}$ & $\begin{array}{l}\text { MTG } \\
\text { (days) }\end{array}$ & $\begin{array}{l}T_{0} \\
\text { (days) }\end{array}$ & $\begin{array}{l}T_{50} \\
\text { (days) }\end{array}$ & $\begin{array}{l}\text { day } \\
\text { temp }\end{array}$ & $\begin{array}{l}\text { night } \\
\text { temp }\end{array}$ & month & $\begin{array}{l}\text { mean } \\
\text { temp }\end{array}$ & \%germ & $\begin{array}{l}\text { MTG } \\
\text { (days) }\end{array}$ & $\begin{array}{l}T_{0} \\
\text { (days) }\end{array}$ & $\begin{array}{l}T_{50} \\
\text { (days) }\end{array}$ \\
\hline Acacia besleyi & 23.4 & 11.6 & Apr & 17.5 & 97.3 & 9.4 & 6.2 & 7.8 & 26 & 14.1 & Apr & 20.1 & 97.3 & 8.8 & 5.4 & 7.4 \\
\hline Acacia bifaria & 19.0 & 7.1 & Sep & 13.1 & 89.4 & 15.4 & 8.2 & 8.9 & 19.3 & 9.7 & Jun & 14.5 & 88.8 & 12.4 & 7.7 & 8.2 \\
\hline Acacia disticha & 22.6 & 10.6 & Jun & 16.6 & 97.9 & 14.5 & 9.2 & 13.4 & 25.1 & 12.9 & Jul & 19.0 & 96.9 & 16 & 10.4 & 13.4 \\
\hline Acacia durabilis & 16.9 & 7.7 & Jun & 12.3 & 94.2 & 14.5 & 11.8 & 9.6 & 19.4 & 9.4 & Jun & 14.4 & 95.2 & 16.7 & 10.8 & 9.2 \\
\hline Acacia heterochroa & 19.0 & 8.5 & May & 13.8 & 98.5 & 12.6 & 8.8 & 8.6 & 18.8 & 9.2 & Jun & 14.0 & 98.8 & 11.9 & 8.2 & 8.0 \\
\hline Acacia ophiolithica & 23.7 & 11.9 & Apr & 17.8 & 99.4 & 10.8 & 6.7 & 10.2 & 22.4 & 11.9 & May & 17.2 & 99.5 & 10.5 & 6.7 & 9.8 \\
\hline Acacia pinguiculosa & 26.4 & 13.7 & Mar & 20.1 & 98.1 & 9.0 & 6.2 & 7.6 & 26.2 & 14.4 & Apr & 20.3 & 98.2 & 8.6 & 5.7 & 7.1 \\
\hline $\begin{array}{l}\text { Allocasuarina } \\
\text { hystricosa }\end{array}$ & 19.4 & 8.9 & May & 14.2 & 90.7 & 24.2 & 15.7 & 15.1 & 22 & 11.3 & May & 16.7 & 91 & 21.7 & 12.6 & 13.1 \\
\hline Banksia laevigata & 19.3 & 8.9 & May & 14.1 & 90.3 & 28.9 & 21.8 & 19.9 & 19.1 & 9.5 & Jun & 14.3 & 90.8 & 28.9 & 22.1 & 19.7 \\
\hline Beaufortia orbifolia & 16.2 & 6.9 & Jun & 11.6 & 93.5 & 24.5 & 18.1 & 18.5 & 18.1 & 8.1 & Jul & 13.1 & 92.5 & 25.3 & 19.6 & 20.8 \\
\hline Calothamnus roseus & 16.7 & 7.1 & Jul & 11.9 & 96.5 & 25.2 & 19.1 & 25.5 & 19.4 & 9.3 & Jul & 14.4 & 90 & 23.7 & 16.0 & 22.8 \\
\hline Daviesia megacalyx & 18.9 & 8.4 & May & 13.7 & 69.9 & 31.1 & 30.4 & 34.2 & 18.7 & 9.0 & Jun & 13.9 & 73.2 & 31.7 & 29.7 & 32.9 \\
\hline Eucalyptus cernua & 17.5 & 8.2 & Jun & 12.9 & 59.4 & 27.4 & 18.5 & 30.4 & 19.9 & 10.3 & Jun & 15.1 & 58.4 & 25.4 & 15.7 & 28.7 \\
\hline $\begin{array}{l}\text { Eucalyptus } \\
\text { desmondensis }\end{array}$ & 19.9 & 9.5 & May & 14.7 & 88.0 & 18.2 & 13.3 & 16.3 & 19.6 & 10.0 & Jun & 14.8 & 88.6 & 17.5 & 12.8 & 16.0 \\
\hline $\begin{array}{l}\text { Eucalyptus } \\
\text { megacornuta }\end{array}$ & 25.9 & 13.0 & Mar & 19.5 & 88.9 & 23.5 & 14.9 & 22.5 & 25.7 & 13.8 & Apr & 19.8 & 89.6 & 23.0 & 14.1 & 22.0 \\
\hline Eucalyptus stoatei & 19.9 & 9.5 & May & 14.7 & 81.3 & 20.9 & 15.7 & 24.6 & 19.6 & 10.0 & Jun & 14.8 & 82.1 & 20.4 & 15.3 & 23.8 \\
\hline $\begin{array}{l}\text { Isopogon sp. } \\
\text { Ravensthorpe }\end{array}$ & 16.5 & 6.1 & Aug & 11.3 & 24.8 & 26.2 & 26.2 & 20.9 & 19.5 & 8.4 & Aug & 13.9 & 17.7 & 29.2 & 29.2 & 24.7 \\
\hline Kunzea acicularis & 18.7 & 6.8 & Sep & 12.8 & 69.2 & 37.9 & 28.7 & 37.5 & 19.3 & 8.3 & Aug & 13.8 & 66.6 & 37.9 & 28.7 & 37.9 \\
\hline Melaleuca penicula & 28.9 & 13.8 & Jan & 21.4 & 93.5 & 13.7 & 8.9 & 13.5 & 30.4 & 16.7 & Feb & 23.6 & 95.4 & 10.8 & 6.5 & 10.7 \\
\hline $\begin{array}{l}\text { Melaleuca } \\
\text { stramentosa }\end{array}$ & 16.5 & 7.0 & Jul & 11.8 & 89.1 & 27.1 & 21.3 & 26.7 & 19.2 & 9.2 & Jul & 14.2 & 86.2 & 24.9 & 17.8 & 24.6 \\
\hline
\end{tabular}

$T_{0}=$ time to initial germination; $T_{50}=$ time to $50 \%$ germination .

4), although the mean temperature described germination rate responses best for the two Melaleuca species. Model 3 (amplitude of temperature alone) was a consistently poor predictor of germination performance. The best fit model results indicate that light was a significant explanatory factor for percentage germination for only five species (A. ophiolithica, Allocasuarina hystricosa, E. cernua, E. megacornuta and M. stramentosa), and the timing of light during the diurnal cycle for germination rate (MTG, $T_{0}$ or $T_{50}$ ) was significant for only three species. Table S1 details the best fitting modelled germination parameters (percentage germination and germination timing, MTG, $T_{0}$ and $\left.T_{50}\right)$ under predicted current and future temperatures.

The extent to which the observed data fit the predicted current percentage germination values was generally good and there were few significant differences between observed and predicted germination values (goodness of fit determined by Pearson's R; Table S2). The exceptions were E. desmondensis, E. megacarpa, Isopogon sp. Ravensthorpe, K. acicularis and $M$. stramentosa. The differences between the observed percentage germination data obtained experimentally on the temperature gradient plate and the modelled responses for current and 2070 forecast diurnal temperature conditions show that variance was usually higher for the observed data $\left(r^{2}=0.5793\right.$ when $K$. acicularis was removed from the dataset due to its anomalous values) than the predicted data $\left(r^{2}=0.9634\right.$ current, $r^{2}=0.946$ future; Fig. 3). The models consistently predicted the number of days to achieve MTG, $T_{0}$ and $T_{50}$ would be greater by 2070 than that provided by the empirical data, but there were some differences between predicted current and forecast future values for these parameters for the 20 species, with MTG increasing or decreasing slightly (maximum 3 days) by 2070, dependent on species (Table 3 ). Twelve of the species are predicted to delay germination and shift optimal germination timing 1 month later and one species (K. acicularis) will shift timing earlier by 1 month. The optimal month for germination is predicted to stay the same for the remaining seven species. The modelled germination results for each of the species investigated highlights the difference between the current and future values for percentage germination and mean time to germination (Figure S3).

From the modelled data, small declines in percentage germination were predicted for nine species as mean temperatures rose (Table 3). These included Isopogon sp. Ravensthorpe, Calothamnus roseus, M. stramentosa, K. acicularis, E. cernua, Beaufortia orbifolia, A. disticha and A. bifaria in order of size of declines (from $7 \%$ to $<1 \%$ of original germination). These predicted changes in optimum germination are plotted against forecast change in mean monthly temperatures (Fig. 4). The remaining species were predicted to slightly increase their final germination, notably D. megacalyx, by $3 \%$. 


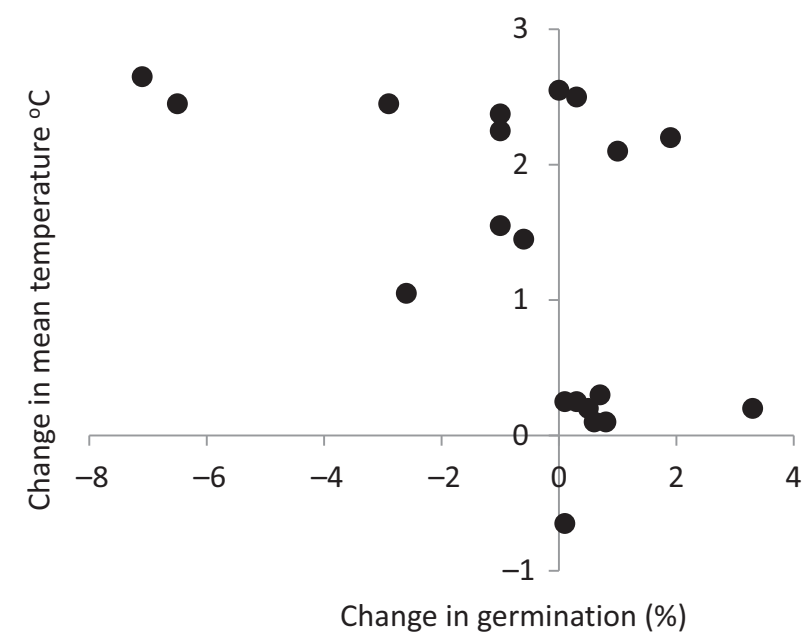

Fig. 4. Difference between current and 2070 forecast mean temperatures for germination and predicted germination change for 20 short-range endemic species from the Ravensthorpe Range. The data are for modelled optimum germination only.

\section{DISCUSSION}

Single-species approaches are powerful tools for projecting the future fate of a focal species; however, exploring germination strategies in a suite of co-occurring species helps to identify patterns and processes in community assembly (Jiménez-Alfaro et al. 2016), including the opportunity for species coexistence (Chesson 2000; Gremer \& Venable 2014). This current study examined the response to warming temperatures in a group of co-occurring short-range endemic species from a biodiverse vegetation community in southern Western Australia. The expectation was that species from this cool winter rainfall region would experience a reduction in germination by 2070 relative to current conditions, and a shift in optimum germination timing due to the forecast seasonal changes; however, the other hypothesis would have been an increase in germination with rising temperatures, as evidenced in cooler climates (e.g. see Milbau et al. 2009). In contrast to expectations, most species appeared to have high resistance to temperature stress during the germination stage of the life cycle, albeit in the presence of constant moisture. When germination was modelled against the mean annual temperature increase of $2.7^{\circ} \mathrm{C}$, and minimum and maximum mean monthly temperatures rises of 2.1 and $3.2{ }^{\circ} \mathrm{C}$, respectively, 11 of the 20 species investigated were not predicted to experience germination declines. Most species had the capacity to tolerate some increase in temperatures during germination, but the increases predicted were small $(<1 \%$ to $3 \%)$. Nine species were predicted to show slight percentage germination declines mostly in the order of less than $5 \%$, although two species showed slightly higher declines (6.5-7.0\%).

There was some discrepancy in the model fit between observed and predicted values for percentage germination for some species (e.g. E. desmondensis, E. megacarpa, Isopogon sp. Ravensthorpe, $K$. acicularis and $M$. stramentosa), which is not fully understood although may be due to a number of reasons: lack of germination pattern across the TGP, or when germination occurred at high temperatures outside known temperature ranges for the species ( $K$. acicularis), or when few cells in the TGP recorded germination (e.g. Isopogon sp. Ravensthorpe), or simply due to the low number of seeds and lack of replication of the experimental treatments. The small sample sizes used in the germination tests and lack of replication mean that results must inevitably be viewed with caution: this investigation should be viewed as a screening of multiple species for possible vulnerabilities to rises in temperature rather than a fully replicated robust set of experiments. Nonetheless, this suite of short-range endemic species has demonstrated a similar variable response to global warming as other woody (Cochrane 2016, 2017) and non-woody (Dwyer \& Erickson 2016) species from the region. Despite some small predicted declines in germination, none are expected to suffer major collapses due to changes in temperature. However, seeds were of different ages and many stored for several years prior to use. Although storage did not impact on final germination as germination was high for most species, storage conditions can induce or release seeds from dormancy thereby modifying seed responses to temperature, so this is acknowledged as a limitation.

The region has a long history of climatic stability (Hopper et al. 2016) but is nonetheless environmentally heterogeneous (Hope et al. 2015). Many plant species have flexible germination strategies to cope with environmental uncertainty (Nicotra et al. 2010). This flexibility may promote co-existence in vegetation communities under current climates (Turcotte \& Levine 2016) and, similarly, flexible germination responses may allow populations to establish and persist as global temperatures rise (Clauss \& Venable 2000) provided seeds can recognise and respond to optimal conditions when they arise (Donohue et al. 2010). Quantifying tolerance to thermal extremes however can be easily underestimated, as seeds under natural conditions experience multiple global change drivers simultaneously, a factor which may erode their flexibility (Valladares et al. 2007).

Although minimal changes to final germination were seen, rising temperatures will be accompanied by substantial declines in winter and spring (and annual) rainfall (Hope et al. 2015). Moisture is an important niche determiner, with heat stress tolerance during seedling germination and emergence inextricably linked to water deficit. Shifts in timing of optimum germination events are likely, in particular as a result of declining autumn-winter rainfall. Changing environmental conditions will set limits on germination and seedling establishment but little is known of how these will impact on endemic species of the region. It is possible that the window of opportunity for germination will narrow, with later germination increasing the risk of exposure to unfavourable conditions. These shifts in germination timing will be in response to both temperature and moisture conditions. Delayed germination is an example of a diversified bet-hedging strategy (Venable 2007; Childs et al. 2010) and trade-offs between germination traits (e.g. faster but lower germination or slower but higher germination) may limit the ability of species to adapt to a changing climate. Early germination may enhance plant fitness (Verdú \& Traveset 2005) but does not necessarily result in successful establishment, and only one species in this study was predicted to advance germination. Overall, it appears that germination will occur later under global warming scenarios for 2070 as a shift in the commencement of germination seems inevitable. Alteration to germination timing can have potential consequences for whole plant life cycle and plant fitness (Walck et al. 2011). Timing of germination determines the conditions under which a seedling can establish (Donohue 2005a) and can influence 
fitness, growth and survival of a population (Donohue 2005a,b; Verdú \& Traveset 2005).

Short-range endemics may be confined to particular locations not due to suitability of the climate, rather due to unsuitability of other environmental conditions, such as soil properties, or due to dispersal limitations or biotic interactions. Some species also do not require seedling recruitment for population persistence in the medium term due to the ability to resprout after disturbance such as fire (e.g. Allocasuarina hystricosa, E. desmondensis and Isopogon sp. Ravensthorpe). This may explain low germination, but not predicted values - seed of the Isopogon is predicted to experience germination decline by 2070. However, in this species, results need to be viewed with caution as germination only occurred in a small number of cells on the gradient plate and thus modelling of the observed data is likely flawed.

\section{CONCLUSIONS}

Predicting the effects of global change on terrestrial plant communities is crucial to managing and conserving plant diversity at all levels. The assumption that species are in equilibrium with current climates, and that climate controls distributions via physiological tolerance to climate variables such as temperature, does not hold in all circumstances. Species with narrow realized niches may not necessarily reflect species climate tolerances and, consequently, these tolerances may be underestimated, as evidenced here. This study contributes to a growing body of literature describing the germination responses of short-range endemic species from a floristically diverse region in Western Australia and provides insight into species-specific responses and their capacity to cope with thermal stresses outside current thermal niches. Even so, lab-based investigations using one climate variable have less ecological validity than field experiments, and models are not infallible. Our knowledge of field germination is inadequate, and whether species can perceive favourable conditions for field germination and the fitness consequences of such germination timing requires further investigation. The flexibility in regeneration traits and the occupation of different germination niches seen here may explain the stability of species-rich communities and the co- existence of endemic species under current climates, but we really do not know whether this flexibility will promote or destabilise species coexistence under future climates when we consider co-occurring stressors. Species that have more flexible temperature responses are likely to gain advantage over slowerresponding species and be favoured under climatic change, but they may upset an already established balance.

\section{ACKNOWLEDGEMENTS}

I would like to thank staff of the Western Australian Department of Biodiversity, Conservation and Attraction, in particular Sarah Barrett, Andrew Crawford and Ben Bayliss, for assistance with the collection of material from the Ravensthorpe Range. I am grateful to the anonymous reviewers for their comments and suggestions that have greatly improved this paper.

\section{SUPPORTING INFORMATION}

Additional supporting information may be found online in the Supporting Information section at the end of the article.

Figure S1. Schematic of diurnal temperatures (day/night ${ }^{\circ} \mathrm{C}$ ) recorded on the temperature gradient plate.

Figure S2. Mean diurnal temperature for germination plotted against time in days to first germination ( $T_{0}-$ left panels) and time in days to $50 \%$ germination ( $T_{50}$ - right panels) for 20 species.

Figure S3. The predicted percentage germination and mean time to germination (MTG) by month for 20 short range endemic species from the Ravensthorpe Range.

Table S1. Summary of analyses (degrees of freedom df, the probability $F$, its significance $P$ and the significance of the photoperiod) for the four models and their temperature variables for each of the 20 species from the Ravensthorpe Range.

Table S2. Number of seeds per dish used in the experiments and the Pearson's correlation coefficient (Pearson's $R$ ) used to test for goodness of fit for the best fit model for each species for the four germination parameters measured.

\section{REFERENCES}

Barrett S., Comer S., McQuoid N., Porter M., Tiller C., Utber D. (2009) Identification and Conservation of Fire Sensitive Ecosystems and Species of the South Coast Natural Resource Management Region. Department of Conservation and Land Management. Albany, Australia.

Bell D.T., Plummer J.A., Taylor S.K. (1993) Seed germination ecology in southwestern Western Australia. The Botanical Review, 59, 25-73.

Bernareggi G., Carbognani M., Mondoni A., Petraglia A. (2016) Seed dormancy and germination changes of snowbed species under climate warming: the role of pre- and post-dispersal temperatures. Annals of Botany, 118, 529-539.

Chesson P. (2000) Mechanisms of maintenance of species diversity. Annual Review of Ecology and Systematics, 31, 343-366.

Childs D.Z., Metcalf C.J.E., Rees M. (2010) Evolutionary bet-hedging in the real world: empirical evidence and challenges revealed by plants. Proceedings of the
Royal Society of London, series B: Biological Sciences, 277, 3055-3064.

Clauss M.J., Venable D.L. (2000) Seed germination in desert annuals: an empirical test of adaptive bet hedging. The American Naturalist, 155, 168-186.

Cochrane A. (2016) Can sensitivity to temperature during germination help predict global warming vulnerability? Seed Science Research, 26, 14-29.

Cochrane A. (2017) Modelling seed germination response to temperature in Eucalyptus L'Her. (Myrtaceae) species in the context of global warming. Seed Science Research, 27, 99-109.

Cochrane A., Kelly A., Brown K., Cunneen S. (2002) Relationships between seed germination requirements and ecophysiological characteristics aid the recovery of threatened native plant species in Western Australia. Ecological Management and Restoration, 3, 45-58.

Cochrane A., Daws M.I., Hay F.R. (2011) Seed-based approach for identifying flora at risk from climate warming. Austral Ecology, 36, 923-935.
Cochrane A., Hoyle G.L., Yates C.J., Wood J., Nicotra A.B. (2014) Predicting the impact of increasing temperatures on seed germination among populations of Western Australian Banksia (Proteaceae). Seed Science Research, 24, 195-205.

Daws M.I., Burslem D.F.R.P., Crabtree L.M., Kirkman P., Mullins C.E., Dalling J.W. (2002) Differences in seed germination responses may promote coexistence of four sympatric Piper species. Functional Ecology, 16, 258-267.

Donohue K. (2005a) Niche construction through phenological plasticity: life history dynamics and ecological consequences. New Phytologist, 166, 83-92.

Donohue K. (2005b) Seeds and seasons: interpreting germination timing in the field. Seed Science Research, 15, 175-187.

Donohue K., Rubio de Casas R., Burghardt L., Kovach K., Willis C. (2010) Germination, postgermination adaptation, and species ecological ranges. Annual Review of Ecology, Evolution, and Systematics, 41, 293-319.

Dwyer J.M., Erickson T.E. (2016) Warmer seed environments increase germination fractions in 
Australian winter annual plant species. Ecosphere, 7, e01497.

Emery N.J., Henwood M.J., Offord C.A., Wardle G.M. (2017) Right here, right now: populations of Actinotus helianthi differ in their early performance traits and interactions. Austral Ecology, 42, 367-378.

Fernández-Pascual E., Jiménez-Alfaro B., Díaz T. (2013) The temperature dimension of the seed germination niche in fen wetlands. Plant Ecology, 214, 489-499.

Fernández-Pascual E., Seal C.E., Pritchard H.W. (2015) Simulating the germination response to diurnally alternating temperatures under climate change scenarios: comparative studies on Carex diandra seeds. Annals of Botany, 115, 201-209.

Fick S.E., Hijmans R.J. (2017) Worldclim 2: new 1-km spatial resolution climate surfaces for global land areas. International Journal of Climatology, 37, 4302-4315.

Gremer J.R., Venable D.L. (2014) Bet hedging in desert winter annual plants: optimal germination strategies in a variable environment. Ecology Letters, 17, 380-387.

Grubb P.J. (1977) The maintenance of species-richness in plant communities: the importance of the regeneration niche. Biological Reviews, 52, 107-145.

Hernández-Verdugo S., Oyama K., Vázquez-Yanes C. (2001) Differentiation in seed germination among populations of Capsicum annuum along a latitudinal gradient in Mexico. Plant Ecology, 155, 245-257.

Hope P., Abbs D., Bhend J., Chiew F., Church J., Ekström M., Kirono D., Lenton A., Lucas C., McInnes K., Moise A., Monselesan D., Mpelasoka F., Timbal B., Webb L., Whetton P. (2015) Southern and South-Western Flatlands cluster report. In: Ekström M., Whetton P., Gerbing C., Grose M., Webb L., Risbey J. (Eds), Climate change in Australia projections for Australia's Natural Resource Management Regions. CSIRO and Bureau of Meteorology, Canberra, ACT, Australia, pp 1-58.

Hopper S.D., Gioia P. (2004) The Southwest Australian Floristic Region: evolution and conservation of a global hot spot of biodiversity. Annual Review of Ecology, Evolution, and Systematics, 35, 623-650.

Hopper S.D., Silveira F.A.O., Fiedler P.L. (2016) Biodiversity hotspots and Ocbil theory. Plant and Soil, 403, 167-216.
Hudson A.R., Ayre D.J., Ooi M.K.J. (2015) Physical dormancy in a changing climate. Seed Science Research, 25, 66-81.

IPPC (2013) Climate change 2013: The physical science basis. Contribution of Working Group I to the Fifth Assessment Report of the Intergovernmental Panel on Climate Change. Cambridge University Press, Cambridge, UK and New York, NY, USA.

Jiménez-Alfaro B., Silveira F.A.O., Fidelis A., Poschlod P., Commander L.E. (2016) Seed germination traits can contribute better to plant community ecology. Journal of Vegetation Science, 23, 637-645.

Jones C.D., Hughes J.K., Bellouin N., Hardiman S.C., Jones G.S., Knight J., Liddicoat S., O'Connor F.M., Andres R.J., Bell C., Boo K.O., Bozzo A., Butchart N., Cadule P., Corbin K.D., Doutriaux-Boucher M., Friedlingstein P., Gornall J., Gray L., Halloran P.R., Hurtt G., Ingram W.J., Lamarque J.F., Law R.M., Meinshausen M., Osprey S., Palin E.J., Parsons Chini L., Raddatz T., Sanderson M.G., Sellar A.A., Schurer A., Valdes P., Wood N., Woodward S., Yoshioka M., Zerroukat M. (2011) The HadGEM2-ES implementation of CMIP5 centennial simulations. Geoscientific Model Development, 4, 543-570.

Markey A., Kern S., Gibson N. (2012) Floristic communities of the Ravensthorpe Range, Western Australia. Conservation Science, 8, 187-239.

Milbau A., Graae B.J., Shevtsova A., Nijs I. (2009) Effects of a warmer climate on seed germination in the subarctic. Annals of Botany, 104, 287-296.

Mittermeier R.A., Turner W.R., Larsen F.W., Brooks T.M., Gascon C. (2011) Global biodiversity conservation: the critical role of hotspots. In: Zachos F. E., Habel J. C. (Eds), Biodiversity hotspots: Distribution and protection of conservation priority areas. Springer, Berlin, Germany, pp 3-22.

Moss R.H., Edmonds J.A., Hibbard K.A., Manning M.R., Rose S.K., van Vuuren D.P., Carter T.R., Emori S., Kainuma M., Kram T., Meehl G.A., Mitchell J.F.B., Nakicenovic N., Riahi K., Smith S.J., Stouffer R.J., Thomson A.M., Weyant J.P., Wilbanks T.J. (2010) The next generation of scenarios for climate change research and assessment. Nature, 463, 747756.
Nicotra A.B., Atkin O.K., Bonser S.P., Davidson A.M., Finnegan E.J., Mathesius U., Poot P., Purugganan M.D., Richards C.L., Valladares F., van Kleunen M. (2010) Plant phenotypic plasticity in a changing climate. Trends in Plant Science, 15, 684-692.

Probert R.J. (2000) The role of temperature in the regulation of seed dormancy and germination. In: Fenner M. (Ed), Seeds. The ecology of regeneration in plant communities, CAB International, Wallingford, UK, pp 261-292.

Roberts E.H. (1988) Temperature and seed germination. Symposium of the Society for Experimental Biology, 42, 109-132.

Smith M.G., Jones A. (2018) Threatened and priority flora list for Western Australia. Department of Biodiversity, Conservation and Attractions, Kensington, WA, Australia.

Torres-Martínez L., Weldy P., Levy M., Emery N.C. (2017) Spatiotemporal heterogeneity in precipitation patterns explain population-level germination strategies in an edaphic specialist. Annals of Botany, 119, 253-265.

Turcotte M.M., Levine J.M. (2016) Phenotypic plasticity and species coexistence. Trends in Ecology \& Evolution, 31, 803-813.

Valladares F., Gianoli E., Gómez J.M. (2007) Ecological limits to plant phenotypic plasticity. New Phytologist, 176, 749-763.

Venable D. (2007) Bet hedging in a guild of desert annuals. Ecology, 88, 1086-1090.

Verdú M., Traveset A. (2005) Early emergence enhances plant fitness: a phylogenetically controlled meta-analysis. Ecology, 86, 1385-1394.

Walck J.L., Hidayati S.N., Dixon K.W., Thompson K., Poschlod P. (2011) Climate change and plant regeneration from seed. Global Change Biology, 17, 21452161.

Wilkins C., Kern S., Rathbone D., Adrienne M. (2011) Rare and poorly known flora of the Ravensthorpe Range and Bandalup Hill Western Australia. Department of Environment and Conservation, Perth, WA, Australia.

Witt W.K. (1997) Geology of the Ravensthorpe and Cocanarup 1:100,000 Sheets. Geological Survey of Western Australia, Perth, WA, Australia. 